\author{
V.V. Bachynckyi, Cand. Sc. (Tech.), Senior Research \\ Fellow, \\ orcid.org/0000-0003-2187-8616, \\ N. R. Antoniuk, Cand. Sc. (Tech.), Assoc. Prof., \\ orcid.org/0000-0003-1730-0723
}

Odesa State Academy of Civil Engineering and Architecture, Odesa, Ukraine, e-mail: slawa_dk@ukr.net

\title{
TECHNOLOGY OF OBTAINING INTUMESCENT FIRE RETARDANT MASTICS
}

Purpose. Increased protection of structures of the mining and chemical industries in case of fires by improving the technology for producing intumescent fire retardant mastics.

Methodology. Theoretical method for studying the technology of producing intumescent fire retardant mastic based on previously obtained experimental data.

Findings. The compositions of intumescent fire retardant mastics, the procedure for applying new compositions are developed and substantiated, which will allow increasing the fire resistance of the surfaces of structures of the mining and chemical industries.

Originality. The possibility is shown of increasing the fire resistance of coatings by improving their composition, which will significantly protect building structures from the occurrence of fires through the use of intumescent fire retardant mastics. The analysis of the mechanism for obtaining the necessary structure of intumescent coatings is disclosed and the technology of their deposition is improved.

Practical value. The impact of changes in various components of intumescent coatings using different amounts of additives, fillers and plasticizers on the most important operational and physico-mechanical properties of the new protective material was evaluated. This will increase the fire protection of various structures of the mining and chemical industries, which in turn will lead to an increase in the time to eliminate fire and to reduce the threat of service personnel from the technological and environmental disasters.

Keywords: flame retardants, intumescent coatings, fire resistance limit, volumetric expansion

Introduction. The development of modern technology in the world leads to the emergence of new substances and their various compounds. Every year their number increases by 200-1000 new substances, which leads to an increase in the already large number of incidents while working at enterprises in the mining and chemical industries. Analysis of the causes of major accidents followed by fire showed that today, in spite of all the protective measures taken by the heads of enterprises, the probability of accidents and catastrophes remains very high [1]. The number of accidents that lead to a fire does not decrease [2]. The increase in fire resistance of the protected structures remains an important component in ensuring the protection of the personnel of the enterprise and its equipment against fires of various kinds [3].

Fire retardant mastics are in high demand for the treatment of surfaces that are or can be subjected to high temperature. The properties of flame retardant mastic under conditions of temperature increase from exposure to fire include the following: imparting fire resistance to the protected surfaces, preventing their ignition, preserving for a long time the operational and physical and mechanical properties of various coatings to which intumescent mastics can be applied and most importantly - increasing the time to eliminate the effects of fire.

Intumescent mastics during their application will slightly add thickness to the coating (putting them on top of the existing material) and will not particularly increase the load on the structure of the structure by increasing the coating mass. Intumescent mastics, in our opinion, should become the most common materials for fire protection of structures of the mining and chemical industries. This material can be applied in a small layer and during the use of structures in the process of their application, intumescent mastics will have not only protective properties, but also decorative and aesthetic. During exposure to elevated temperature (or direct open fire), the mastic will begin to swell and bloat, increasing significantly from its original volume, forming a protective layer. The relevance of the study of compositions of intumescent mastics with increased temperature-protective characteristics is associated with the calculations of the optimal composition of mastic, which will ensure maximum expansion, reliability and

(C) Bachynckyi V.V., Antoniuk N. R., 2019 cohesion of the entire thickness of the layer when exposed to elevated temperatures. Also, this composition will increase adhesion to the substrate, while maintaining the basic decorative, aesthetic and protective properties during the operation of structures and structures.

Literature review. Today, in our opinion, the most interesting and widely used way to increase the fire resistance of building structures remains the use of intumescent fire retardant mastics. Currently, there are more than one hundred valid certificates of various compositions for the protection of wooden products for various purposes and more than three hundred certificates for metal structures $[4,5]$.

The absence of reliable and truthful data and recommendations in specialized publications, on the websites of leading manufacturers or other media does not allow for an objective analysis of various fire retardant materials for a comparative description of their competitiveness [6].

It is natural that the most truthful information about the work of flame retardant mastic during ignition, changes in its structure and the duration of the protective function of the applied coating can be obtained only during a full-scale experiment [7]. At the same time, the main requirement for such mastics during their operation under the influence of fire remains the preservation of their flame retardant functions, but not the possible loss of the appearance of the building structure with a possible reduction of the flame retardant properties [8].

The analysis of publications showed that the consumption of intumescent mastic for wood products, which is necessary to obtain 1 group of fire protection, will be $450-500 \mathrm{~g} / \mathrm{m}^{2}$.

Analysis of the use of intumescent mastic to protect coatings with a metal base showed that the average thickness of the applied layer of $30-35 \mathrm{~mm}$ will increase the fire resistance of metal products and structures to 2 groups of flame retardant efficiency, and with a layer thickness of $35-40 \mathrm{~mm}$ it is possible to provide already 1 group of fire protection.

At the same time, the optimization of the structure and possibilities of such a coating will make it possible to find the optimal composition of the intumescent mastic for the specific conditions of its application.

Purpose. Increasing the fire protection of buildingstructures of the mining and chemical industries by improving the technology for producing intumescent fire retardants. 
The composition of the investigated coatings

\begin{tabular}{|l|c|c|c|c|c|c|c|c|c|c|c|}
\hline \multirow{2}{*}{\multicolumn{1}{c|}{ Components }} & \multicolumn{10}{|c|}{ Content, parts by weight, in the composition } \\
\cline { 2 - 14 } & 1 & 2 & 3 & 4 & 5 & 6 & 7 & 8 & 9 & 10 \\
\hline Chloroprene rubber & 100 & 100 & 100 & 100 & 100 & 100 & 100 & 100 & 100 & 100 \\
\hline Naphtham-2 (neozone D) & 0.5 & 0.75 & 1 & 1.25 & 1.5 & 1.75 & 2 & 2.25 & 2.5 & 3 \\
\hline Antimony trioxide & 3 & 3.5 & 4 & 4.5 & 5 & 5.5 & 6 & 6.5 & 7 & 7.5 \\
\hline Chloroparaffin & 5 & 6 & 7 & 8 & 9 & 10 & 11 & 12 & 13 & 14 \\
\hline Aluminum hydroxide & 14 & 15 & 16 & 17 & 18 & 19 & 20 & 21 & 22 & 23 \\
\hline Graphite & 24 & 25 & 26 & 27 & 28 & 29 & 30 & 31 & 32 & 33 \\
\hline Phenol formaldehyde resin & 20 & 40 & 60 & 80 & 100 & 120 & 140 & 160 & 180 & 200 \\
\hline Ethyl acetate & 300 & 350 & 400 & 450 & 500 & 550 & 600 & 650 & 700 & 750 \\
\hline
\end{tabular}

The main tasks that were solved to achieve the goal of the work are:

1. To analyze the mechanism of operation of intumescent coatings when exposed to high temperatures.

2. To determine the main parameters of the structure of intumescent coatings.

3. To assess the effect of changing the composition intumescent mastics adding various fillers and additives to the material matrix of basic physico-mechanical, decorative and aesthetic, and operational characteristics of the protective coating.

Results. During construction or reconstruction of structures and buildings of the mining and chemical industries, the project always defines the requirements for the degree of fire protection of such an object [9]. These requirements must necessarily include the implementation of various fire prevention measures that fully meet the requirements of state building codes and other governing documents in the field of fire protection and safety. One of such urgent preventive measures, in our opinion, is the improvement of the structure, and accordingly, the optimization of the possibilities of intumescent mastics.

At the same time, modern construction of buildings and structures of the mining and chemical industry still is not conceivable without the use of various metal products. This is especially true of supporting structures, which are based on metal structures. Despite the fact that metal structures made of steel, which form the basis of the supporting structures, look very reliable, if a flame development or fire occurs, they become vulnerable to fire and can lose their structural characteristics even at $500{ }^{\circ} \mathrm{C}$. Due to the high thermal conductivity, in the event of a fire, steel metal structures can lose their effectiveness in 15 minutes.

The use of intumescent mastics can significantly increase the time of protection of metal structures, which will, in turn, ensure the effective protection of the personnel of the enterprise and its equipment against fires of various kinds.

To accomplish the above goals and objectives, it was decided to use the materials presented in Table 1.

Antimony trioxide, chloroparaffin and aluminum hydroxide when interacting with graphite allow obtaining a polymer composition, which swells up during combustion and reduces the spread of the flame.

Antimony trioxide is a white crystal that does not dissolve in water with a density of $5.2 \mathrm{~g} / \mathrm{cm}^{3}$. It is also used as a fire additive in the production of various products - from heat-resistant plastics to overalls and cables.

Chloroparaffin is a white powder with a density of $1.7 \mathrm{~g} / \mathrm{cm}^{3}$, which is used as a plasticizer in the production of various roofing materials, varnishes and emulsions.

Aluminum hydroxide is a solid, colorless material, with a density of $2.4 \mathrm{~g} / \mathrm{cm}^{3}$, which, as a rule, is used as a sorbent as well as while manufacturing plastic products.
The introduction of naphtam-2 (neozon D), gray powder, as an anti-aging component, improves the resistance of the composition to various types of aging with a melting point of $105^{\circ} \mathrm{C}$.

Chloroprene rubber, which has good resistance to open fire, was used as a polymer base.

Graphite is a mineral material of black color which was used in the work as a filler and intumescent component.

Phenol-formaldehyde resin - a yellow solid with a melting point of $75^{\circ} \mathrm{C}$ was used as an adhesive additive [10].

Ethyl acetate is a colorless liquid with a density of $0.9 \mathrm{~g} / \mathrm{cm}^{3}$, which is used as a solvent.

To evaluate the properties of various compounds of intumescent mastic, 10 polymer compositions were prepared, which differed in their component composition (Table 1). Compositions were prepared according to the technology presented in Fig. 1.

The resulting compositions were a thick viscous mass. It was applied to the protected surface with a thickness of 1, 2 and $3 \mathrm{~mm}$, then dried at a temperature of $20^{\circ} \mathrm{C}$ for $7-8$ hours. The properties of the compositions were determined according to Technical conditions, State standard of Ukraine and other applicable regulatory documents.

With the introduction of fillers and additives into the polymer matrix, as in all heterogeneous systems, intermolecular interaction was observed in the middle of the phases themselves and interfacial interaction also took place.

During the introduction of fillers and additives into the polymer matrix, as in all heterogeneous systems, intermolecular interaction was observed in the middle of the phases themselves and interfacial interaction also occurred.

In spite of the fact that the obtained compositions were applied with a thin layer on a substrate, under fire influence, the intumescent mastic should swell and distend, significantly increasing in volume. At the same time, a layer of hardening

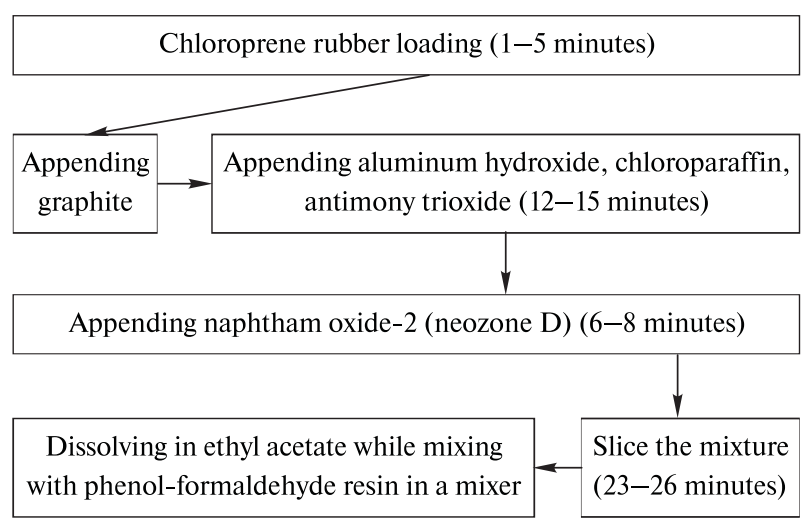

Fig. 1. Technology for intumescent mastics 
The results of the experimental data

\begin{tabular}{|c|c|c|c|c|c|c|c|c|c|c|}
\hline \multirow{2}{*}{ Indicators } & \multicolumn{10}{|c|}{ The composition of the mixtures } \\
\hline & 1 & 2 & 3 & 4 & 5 & 6 & 7 & 8 & 9 & 10 \\
\hline Theoretical density, $\mathrm{g} / \mathrm{cm}^{3}$ & 1.4 & 1.42 & 1.43 & 1.45 & 1.47 & 1.49 & 1.51 & 1.52 & 1.55 & 1.57 \\
\hline Hardness, conv. units & 45 & 45 & 46 & 46 & 47 & 47 & 48 & 49 & 50 & 50 \\
\hline Swelling coefficient & 15 & 17 & 19 & 20 & 23 & 25 & 28 & 29 & 31 & 34 \\
\hline $\begin{array}{l}\text { Time from the date of } \\
\text { manufacture, days }\end{array}$ & 360 & 360 & 360 & 360 & 360 & 360 & 360 & 360 & 360 & 360 \\
\hline Fire protection & $\begin{array}{l}\text { does not } \\
\text { burn }\end{array}$ & $\begin{array}{l}\text { does not } \\
\text { burn }\end{array}$ & $\begin{array}{l}\text { does not } \\
\text { burn }\end{array}$ & $\begin{array}{l}\text { does not } \\
\text { burn }\end{array}$ & $\begin{array}{l}\text { does not } \\
\text { burn }\end{array}$ & $\begin{array}{l}\text { does not } \\
\text { burn }\end{array}$ & $\begin{array}{l}\text { does not } \\
\text { burn }\end{array}$ & $\begin{array}{l}\text { does not } \\
\text { burn }\end{array}$ & $\begin{array}{l}\text { does not } \\
\text { burn }\end{array}$ & $\begin{array}{l}\text { does not } \\
\text { burn }\end{array}$ \\
\hline Volumetric expansion, $\%$ & 205 & 210 & 212 & 217 & 220 & 220 & 222 & 226 & 228 & 236 \\
\hline $\begin{array}{l}\text { The time to reach } \\
\text { a temperature of } 500{ }^{\circ} \mathrm{C} \text {, min: }\end{array}$ & & & & & & & & & & \\
\hline - layer thickness $1 \mathrm{~mm}$ & 39 & 40 & 41 & 42 & 42 & 44 & 44 & 45 & 45 & 45 \\
\hline - layer thickness $2 \mathrm{~mm}$ & 47 & 49 & 52 & 56 & 57 & 59 & 60 & 60 & 60 & 60 \\
\hline - layer thickness $3 \mathrm{~mm}$ & 61 & 64 & 67 & 71 & 74 & 76 & 79 & 85 & 85 & 85 \\
\hline
\end{tabular}

mastic is formed, which will already have a low thermal conductivity and a great resistance to open fire.

The task of the experiment was not to obtain the maximum volumetric expansion of mastics, but to determine the minimum allowable thickness of the original composition (and its constituents in the optimal ratio of fillers and additives) that would protect the protected surface.

This would significantly increase the fire protection of building structures when operating them at enterprises in the mining and chemical industries without using additional technical protective devices. The creation of protected surfaces around the centers of thermal resistance of the flame will not allow metal products to warm up to a critical temperature in a significant period of time. The properties of ten mixtures with different thicknesses of the applied intumescent mastic are presented in Table 2.

The main objective of the experiment was to show how long the material could withstand the effects of temperatures up to $500{ }^{\circ} \mathrm{C}$ on the cold side, which is not facing the fire when applied with different thickness of mastic.

The fire resistance of the specimen with applied intumescent mastic was expressed in minutes from the start of the test (gas burner on) until the metal base was heated from the unheated side to a critical temperature of $500{ }^{\circ} \mathrm{C}$. The tests were carried out according to the scheme of thermal shock at a flame temperature of $720-850{ }^{\circ} \mathrm{C}$. The experiment showed (Table 2) that the optimal flame retardant efficiency is achieved in the eighth composition with a coating thickness of $3 \mathrm{~mm}$. A further increase in the expansion of the coating (compositions nine and ten) does not lead to an increase in the resistance of the structure to the action of high temperatures. On this basis, a further increase in the initial layer of the applied mastic is not necessary, since it no longer increases the time to reach the criterial temperature of $500{ }^{\circ} \mathrm{C}$.

The sample was fixed with a holder in a vertical position. After ignition, the burner was installed under the sample, holding it in a vertical position for $10-15 \mathrm{~s}$, so that the flame had a height of 15-20 mm. After that, the burner was set aside and the duration of independent burning and smoldering of the sample was determined (Fig. 2).

The volumetric expansion of the intumescent mastic was determined using a dilatometer, which is well suited for pasty coatings, measuring the thickness of the sample before and after the effect of fire on the sample.

Analysis of the data showed the advantage of using intumescent compositions. It was found that the metal surface, on which the intumescent fire-retardant composition was ap- plied, significantly increases its fire resistance limit and, accordingly, the strength of the structure or product itself.

Fig. 3 shows the dependence of the temperature of the metalwork with unprotected mastic (1) and of the same design, but protected by fire retardant intumescent mastic at different optimum thickness (2-4). The calculations showed that when protecting metal structures with an intumescent fire-re-

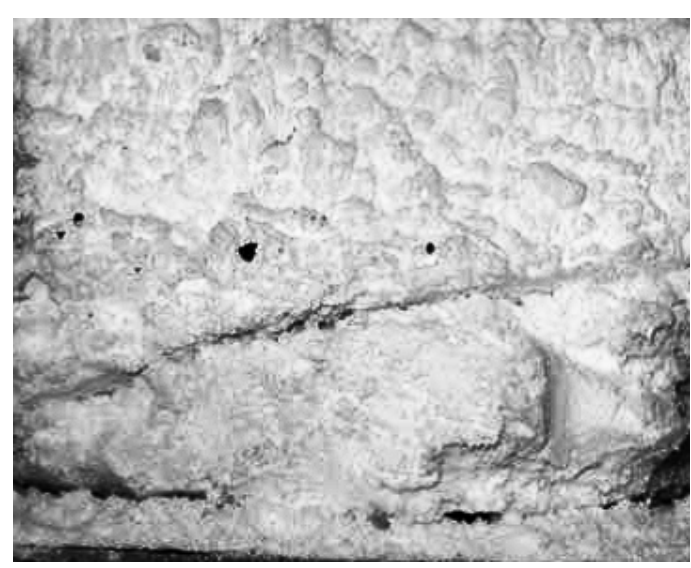

Fig. 2. Fragment of intumescent mastic $(M 1: 1 \mathrm{~cm})$

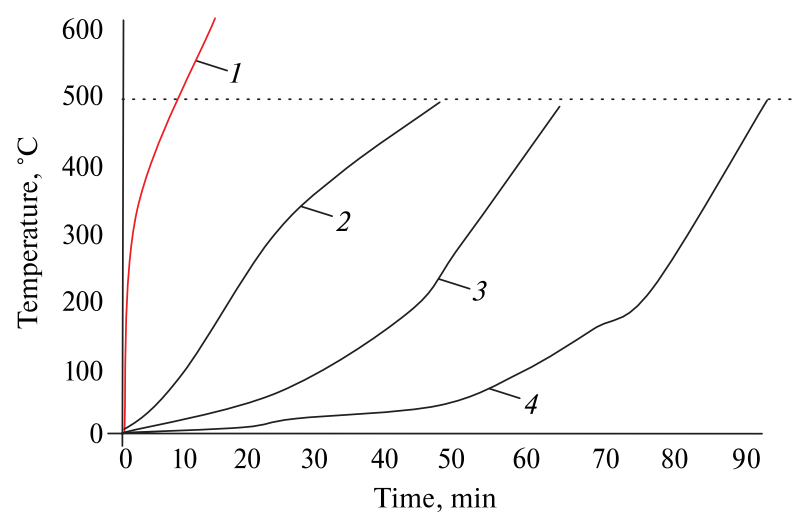

Fig. 3. The dependence of the temperature of the test sample with various flame retardant compounds applied on its surface:

1 - unprotected metalwork; 2 - protected with swelling mastic thickness of $1 \mathrm{~mm} ; 3$ - thickness of $2 \mathrm{~mm} ; 4$ - thickness of $3 \mathrm{~mm}$ 
tardant coating, the limit of fire resistance of the surfaces of building structures of the mining and chemical industries will be significantly increased.

As soon as the surface temperature reaches $+500{ }^{\circ} \mathrm{C}$, the operational properties of the protected metal surfaces begin to change and the sample or product is slowly deformed, which will lead to significant irreversible damage to the products and sometimes even irreversible losses. The proposed intumescent mastics are able to delay the ignition of the protected surfaces, reduce the distribution of fire in the premises or structures of the mining and chemical industries. At the same time, the selection of the optimal number of coating components, the calculation of the required thickness of application of intumescent mastic and obtaining the required volume expansion also significantly depend on the nature of the protected surface and its thickness, which requires additional research.

An increase in the fire protection of the protected metal structures will not only save material assets and equipment of enterprises, but also increase the safety of personnel during ignition, providing an increase in time for evacuation [11]. Increasing the time of ignition of the surfaces of building structures and, accordingly, their durability, we increase the likelihood of personnel withdrawal from a burning building; we increase the time and opportunities for eliminating fires, its safe extinguishing.

However, under conditions of different types of man-made accidents, the heating of metal structures can fundamentally change from heating in the "design fire" mode. The calculated thickness of the layer of intumescent composition in case of fire to determine and carry out the required amount of fire protection of the coating may not always coincide with those shown in the issued recommendations on fire protection and safety. Consequently, it is necessary to calculate in advance the safely allowable thickness of the protective layer and its composition for a specific surface type of objects and structures of the mining and chemical industry, taking into account the peculiarities and possibilities of fire load, while minimizing the costs and expenses of fire protection [12].

Since the mastic has a significantly higher viscosity, the heat transfer due to convection was not taken into account in the calculations. The heat transfer was considered and calculated as a one-dimensional layer of the swelling coating for a flat surface, which has a conditional temperature $T$ and a degree of blackness $E$, parallel to a spaced surface, which has a conditional temperature $T_{2}$ and a degree of blackness $E_{2}$. The space around these surfaces is filled with a mastic conglomerate with a radiation absorption coefficient $\alpha$ and a thermal conductivity coefficient of the intumescent mastic k with the distance $D$ between them.

We considered joint energy transfer independently of each other. Based on this, the general view of the total energy flow can be calculated

$$
q=q_{c}+q_{r}=\frac{k\left(T_{1}-T_{2}\right)}{D}+\frac{\delta\left(T_{1}^{4}-T_{2}^{4}\right)}{\frac{3 \alpha D}{4}+\frac{1}{E}-1} .
$$

Heat conductivity coefficients can be determined using the Mangold equation

$$
k=\frac{2}{3} \alpha k_{e}+(1-\alpha) k_{d},
$$

where $k_{e}$ and $k_{d}$ are values of thermal conductivities of the liquid and air phase; $\alpha$ is the amount of filling with a mastic conglomerate of a liquid (solid) phase; $\delta$ is the Stefan-Boltzmann constant.

The blackness level of mastic $(E)$ in the direction of the normal was calculated as follows

$$
E=1-\left(\frac{n-1}{n+1}\right)^{2}
$$

where $n$ is mean refractive index values in intumescent mastic [13], with

$$
\frac{\sum n_{i} \Delta_{i}}{\Delta}=n
$$

where $\Delta_{i}$ is the thickness of one layer of mastic part in the whole mixture.

Solving (1) with respect to the thickness of a single layer of mastic, it was found that the thickness of the intumescent mastic depends on the thermophysical parameters of the mastic conglomerate and on the radiation properties of the hardened mastic. If the interaction of radiation and heat conduction occurs, the thickness that needs to be calculated cannot be calculated by adding the radiation and conductive components, which are calculated separately from each other. For these purposes, it is necessary to calculate the energy equations, which takes into account the effect of both types of heat transfer.

Intumescent mastics have the following advantages over other flame retardants and materials:

- the applied coating will have a thickness of up to $3 \mathrm{~mm}$, i. e. it is thin layered;

- it is allowed to apply the developed composition at ambient temperature from -5 to $+40{ }^{\circ} \mathrm{C}$ and relative air humidity of $100 \%$.

Practical conditions for the use of intumescent mastic are:

- the painted surface must be cleared out from dirt, dust, oil stains;

- old paint must be removed;

- before using mastic, it must be thoroughly mixed for 2 3 minutes;

- mastic can be applied with a paint brush, and the usual roller.

The resulting intumescent polymer composition does not burn and, during a possible fire or fire, will protect any surfaces of various structures and objects of the mining and chemical industries, while possessing reliable operational, physical, mechanical and technological characteristics.

\section{Conclusions:}

1. Compositions of intumescent mastics and technology of their application to the protected surface has been developed, which can provide a significant increase in the fire resistance of metal structures for a long time.

2. A mechanism has been developed for obtaining the required structure of intumescent coatings.

3 . The influence of various structures of the intumescent coating with different fillers and additives on the basic physicomechanical and operational characteristics of the protected surface was assessed.

4. It is shown that the use of fillers and additives proposed in the work allows preserving the original internal structure of the coating itself and significantly increase the fire resistance of surfaces of building structures of the mining and chemical industries.

\section{References.}

1. Shmandiy, V. M., Kharlamova, E. V., \& Rigas, T. E. (2015). The study of manifestations of environmental hazards at the regional level. Gigiena i Sanitariya, 7, 90-92.

2. Bezsonov, Y., \& Andreiev, V. (2016). Justification and formalization of approach to regional environmental safety evaluation. Eastern-European Journal of Enterprise Technologies, 2(10(80)), 9-18. DOI: 10.15587/1729-4061.2016.64843.

3. Xin, J., \& Huang, C. (2013). Fire Risk Assessment of Residential Buildings Based on Fire Statistics from China, Fire Technology, 50(5), 1147-1161. DOI: 10.1007/s10694-0130327-8.

4. Oreshchenko, A., \& Nesterchuk, I. (2017). Development and use of a geoinformation system for revealing urban problems. Eastern-European Journal of Enterprise Technologies, 2(2(86)), 32-41. DOI: 10.15587/1729-4061.2017.98809. 
5. Vambol, S., Vambol, V., Sychikova, Y., \& Deyneko, N. (2017). Analysis of the ways to provide ecological safety for the products of nanotechnologies throughout their life cycle. Eastern-European Journal of Enterprise Technologies, 1(10(85)), 27-36. DOI: 10.15587/1729-4061.2017.85847.

6. Ministry of Emergencies of Ukraine (2014). National reports on the state of ecological and technogenic safety in Ukraine for 1997-2014. Retrieved from http:// www.mns.gov.ua/content/national_lecture.html.

7. The State Emergency Service of Ukraine (2015). Information and analytical report on emergency situations in Ukraine, which occurred during 2015. Retrieved from http:// www.dsns. gov.ua/ua/Dovidka-za-kvartal/44615.html.

8. Sjostrom, J., Amon, F., Appel, G., \& Persson, H. (2015). Thermal exposure from large scale ethanol fuel pool fires. Fire Safety Journal, 78, 229-237.

9. Jinlong, Zh., Hong, H., Grunde, J., Maohua, Zh., \& Yuntao, L. (2017). Spread and burning behavior of continuous spill/res. Fire Safety Journal, 91, 347-354.

10. Andronov, V., Pospelov, B., \& Rybka, E. (2016). Increase of accuracy of deNnition of temperature by sensors of Nre alarms in real conditions of Nre on objects. Eastern-European Journal of Enterprise Technologies, 4-5(82), 38-44.

11. Rumiantsev, V., Yakubin, N., Bielokon, K., Matukhno, E., \& Leventsova, C. (2015). Ecological aspects of the neutralization of gas emissions leaving from the resin storehouse of joint - stock company "Zaporozhkoks". Metallurgical and Mining Industry, 4, 105-109.

12. Taran, N.A. (2010). Harmonization of standards in time of testing the fire protection means. Pokraska professionalnaya, 4, 6-7.

13. Ivanets, G., \& Gorelyshev, S. (2016). Assessment of anthropogenic-natural-social threats of state regions based on the method of vector-statistical analysis regarding the area and population. Nauchnyy zhurnal "Vlast' i obshchestvo" (Istoriya, Teoriya, Praktika), 3(39), 162-174.

\section{Технологія отримання вогнезахисних мастик, що спучуються}

\section{В. В. Бачинський, Н. Р. Антонюк}

Одеська державна академія будівництва та архітектури, м. Одеса, Україна, e-mail: slawa_dk@ukr.net

Мета. Збільшення захисту конструкцій і споруд гірничодобувної та хімічної промисловості при виникненні пожеж за рахунок удосконалення технології отримання вогнезахисних мастик, що спучуються.

Методика. Теоретичний метод дослідження технології отримання вогнезахисних мастик, що спучуються 3 урахуванням раніше отриманих експериментальних даних.

Результати. Розроблено та обгрунтовано склад вогнезахисних мастик, що спучуються, порядок застосування нових композицій, що дозволить підвищувати межу вогнестійкості поверхонь конструкцій і споруд гірничодобувної та хімічної промисловості.

Наукова новизна. Показана можливість збільшення вогнестійкості покриттів за рахунок удосконалення їх складу, що дозволить істотно убезпечити будівельні конструкції від виникнення загорянь за рахунок застосування вогнезахисних мастик, що спучуються. Розкрито аналіз механізму отримання необхідної структури покриттів, що спучуються та вдосконалена технологія їх нанесення.

Практична значимість. Проведена оцінка впливу зміни різних складових компонентів покриттів, що спучуються при використанні різної кількості добавок, наповнювачів і пластифікаторів на найбільш важливі експлуатаційні та фізико-механічні властивості нового захисного матеріалу. Це дозволить підвищити вогнезахист різних споруд гірничодобувної та хімічної промисловості, що, у свою чергу, призведе й до збільшення часу на ліквідацію пожежі, та до зменшення загрози обслуговуючому персоналу від техногенних та екологічних катастроф.

Ключові слова: вогнезахисні мастики, покриття, що спучується, межа вогнестійкості, об'ємне розширення

\section{Технология получения вспучивающихся огнезашитных мастик}

\section{В. В. Бачинский, Н. Р. Антонюк}

Одесская государственная академия строительства и архитектуры, г. Одесса, Украина, e-mail: slawa_dk@ukr.net

Цель. Увеличение защиты конструкций и сооружений горнодобывающей и химической промышленности при возникновении возгораний за счет совершенствования технологии получения вспучивающихся огнезащитных мастик.

Методика. Теоретический метод исследования технологии получения вспучивающихся огнезащитных мастик с учетом ранее полученных экспериментальных данных.

Результаты. Разработаны и обоснованы составы вспучивающихся огнезащитных мастик, порядок применения новых композиций, что позволит повышать предел огнестойкости поверхностей конструкций и сооружений горнодобывающей и химической промышленности.

Научная новизна. Показана возможность увеличения огнестойкости покрытий за счет совершенствования их состава, что позволит существенно обезопасить строительные конструкции от возникновения возгораний за счет применения вспучивающихся огнезащитных мастик. Раскрыт анализ механизма получения необходимой структуры вспучивающихся покрытий и совершенствована технология их нанесения.

Практическая значимость. Проведена оценка влияния изменения различных составляющих компонентов вспучивающихся покрытий при использовании разного количества добавок, наполнителей и пластификаторов на наиболее важные эксплуатационные и физико-механические свойства нового защитного материала. Это позволит повысить огнезащиту различных сооружений горнодобывающей и химической промышленности, что, в свою очередь, приведет и к увеличению времени на ликвидацию пожара, и к уменьшению угрозы обслуживающему персоналу от техногенных и экологических катастроф.

Ключевые слова: огнезащитные мастики, вспучивающиеся покрытия, предел огнестойкости, объемное расширение

Рекомендовано до публікаиії докт. техн. наук В. М. Вировим. Дата надходження рукопису 28.03.18. 